

\section{de la MUERTE:}


n la cinematografía de ciencia ficción se encuentran algunas de las imágenes más contundentes de la destrucción propiciada por una epidemia. Este género tiene un amplio catálogo de ciudades arrasadas por microorganismos que dejan a su paso catástrofes de tintes medievales en el seno del mundo contemporáneo. Sin embargo, la construcción de ficciones sobre epidemias no solo ha sido un motivo de la ciencia ficción; otros géneros fílmicos han mostrado diversas facetas de las crisis provocadas por patologías misteriosas. El cine se constituye, entonces, como un caleidoscopio que ofrece diversas perspectivas de la batalla entre la humanidad y las enfermedades infecciosas.

\section{Los géneros fantásticos}

El cine llevó al siglo xx el espíritu romántico que prevaleció en un sector del arte decimonónico. La filmografía expresionista abrevó de ese influjo y le dio un nuevo brío de carácter tenebroso, enigmático y diabólico. Las epidemias que aparecen en Nosferatu (Nosferatu, eine Symphonie des Grauens, 1922) y Fausto (Faust: Eine deutsche Volkssage, 1926), dos obras cumbres del expresionismo, demuestran que el poder de la ciencia es insuficiente ante una enfermedad de origen maligno y sobrenatural.

Nosferatu, una adaptación de la novela Drácula (1897) de Bram Stoker, presenta al vampiro como una personificación de la peste. La plaga se extiende en los lugares que visitan el espectro y las ratas que lo acompañan. Por su parte, la película Fausto adapta la monumental pieza teatral de Goethe, publicada en 1808. En las primeras escenas de la cinta, el Diablo provoca la peste y Fausto comprueba que el conocimiento de toda una vida de estudio es insuficiente para hallar la cura. Por lo tanto, hace un pacto satánico que no solo resuelve la epidemia, también le da juventud, fama y poder a cambio de su alma.

La peste es la enfermedad epidémica por antonomasia. En Occidente, las imágenes y relatos de la peste son, en buena medida, una herencia de la cultura medieval. Como ejemplo están las danzas de la muerte o danzas macabras, un género literario y pictórico popular en la Baja Edad Media. Su auge coincidió con momentos de crisis demográficas como la que ocasionó la peste negra en la década de 1340. Las danzas macabras tenían una función aleccionadora debido a que los personajes prototípicos de la cultura medieval — desde los campesinos hasta los nobles y los papasaparecían bailando al compás de la muerte.

Las películas Nosferatu y Fausto se produjeron cuando la peste había perdido su halo misterioso. El microorganismo de la peste fue descubierto en 1894 y el hallazgo permitió delimitar que el proceso de infección comienza cuando las pulgas de las ratas infectadas pican a poblaciones humanas.

El surgimiento cinematográfico de la peste como una enfermedad de origen sobrenatural se explica por el contexto social de las películas expresionistas. El final de la Primera Guerra Mundialllegó con la derrota alemana y el desmoronamiento de su proyecto imperial. En su ensayo sobre el cine clásico alemán, Lotte Eisner (2013) advierte el impacto que tuvo la guerra en el ánimo colectivo: “La hecatombe de jóvenes prematuramente segados parecía nutrir la indomable nostalgia de los sobrevivientes. Y los fantasmas que habían poblado el romanticismo alemán se reavivaban como las sombras del Hades después de beber sangre" (p.13).

Nosferatu y Fausto dan testimonio de la dimensión perturbadora y amenazante que prevalece en la realidad cotidiana del mundo moderno. En la obra de prestigiosos directores como Werner
Herzog e Ingmar Bergman e, incluso, en la de un director de producciones populares como Roger Corman hay ejemplos de películas que siguen la estela fantástica de Friedrich Murnau a la hora de escenificar una epidemia.

El séptimo sello (Det sjunde inseglet, 1957) y La máscara de la muerte roja (The Masque of the Red Death, 1964) en lugar de colocar en el mundo moderno una epidemia antigua, transportan a sus espectadores al mundo medieval. La película de Bergman ha sido interpretada como una ilustración de los efectos de las plagas antiguas para un público que vivía en un contexto histórico en el cual la guerra nuclear podía convertirse en una nueva peste destructora. A su vez, La máscara de la muerte roja, una adaptación del cuento homónimo de Edgar Allan Poe, brinda una lección similar a las de las danzas macabras: nadie es capaz de burlar la muerte, ni siquiera el despiadado príncipe que protagoniza el filme.

Por su parte, Werner Herzog estrenó Nosferatu, el vampiro (Nosferatu: Phantom der Nacht, 1979). Esta versión del clásico de Murnau demuestra el poder de la peste en las imágenes del vampiro, su ejército de ratas y los supervivientes que se entregan al bacanal en las plazas públicas, junto a los féretros pestilentes, los roedores y el ganado que deambula en las calles. La película compone, de este modo, una danza macabra en la cual los condenados a muerte pasan de la incertidumbre a la certeza, del terror a la resignación, del duelo a la lúgubre celebración.

El Nosferatu de Herzog esboza dos interpretaciones antagónicas de la enfermedad. La primera proviene de Lucy, la esposa del agente in mobiliario que es víctima del vampiro. Después de leer un libro que su marido recibió de los campesinos de Transilvania, Lucy cree que Nosferatu provoca la peste. Por su parte, el doctor Van Helsing, un hombre ilustrado, rechaza categóricamente la hipótesis: "Vivimos en la era de las luces. Las supersticiones que usted menciona han sido refutadas por la ciencia". Sin embargo, Van Helsing se equivoca. También en la era moderna la peste se manifiesta como un poder demoniaco.

En el cine de ciencia ficción ese poder maligno suele ser una consecuencia del desarrollo científico. También este género se ha nutrido del romanticismo; uno de sus principales antecedentes es la historia de Frankenstein que Mary Shelley publicó en su novela de 1818. La ciencia ficción comúnmente trata a las bacterias y los virus como los nuevos monstruos de Frankenstein: los microorganismos diseñados en laboratorios escapan al control de sus creadores para destruir a una civilización que intenta controlar las fuerzas de la naturaleza. El catálogo de películas es amplio, pero resultan ejemplares Day of Resurrection (Fukkatsu no hi, 1980), 12 monos (Twelve Monkeys, 1995) y los filmes de 
zombis que usualmente combinan la ciencia ficción y el terror.

El filósofo Jorge Martínez Lucerna (2010,p. 69) dice que la primera gran película de zombis es Muertos vivientes (Invasion of the Body Snatchers, 1956). Esta cinta trata sobre la incursión de una entidad — posiblemente alienígena-que suplanta los cuerpos de los habitantes de un suburbio californiano. La película ejemplifica la paranoia social ante la invasión de un agente invisible capaz de tomar los cuerpos de las personas sin que lo perciban.

Otro referente del cine de zombis y epidemias es la primera adaptación de la novela Soy leyenda (1954) de Richard Matheson. Se trata de Seres en las sombras (The Last Man on Earth, 1964) en la cual una guerra bacteriológica entre China y Estados Unidos transforma a las personas en vampiros. El único superviviente, un científico inmune a la bacteria, pasa las noches en su casa, convertida en un bunker, mientras los vampiros acechan su refugio. La situación se invierte durante el día cuando el científico sale a cazar a los infectados. Los vampiros de Seres en las sombras se parecen más a los muertos vivientes
LAS CRISIS SANITARIAS SON UNA

INSPIRACIÓN PARA EL CINE APOCALÍPTICO.

LOS VIRUS DAN UN MARCO DE

VEROSIMILITUD A LAS FICCIONES

DE CATÁSTROFES EPIDEMIOLÓGICAS.

ESTAMOS ANTE UN ESCAPARATE

DEL IMAGINARIO SOCIAL QUE EXHIBE

LAS ANGUSTIAS DE UNA SOCIEDAD GLOBAL.

de George Romero que al distinguido conde Drácula de Béla Lugosi o Christopher Lee.

George Romero creó los zombis más paradigmáticos: una multitud de muertos que se levantan de sus tumbas con el impulso insaciable de comer carne. Este engendro del consumo que se mueve en masa es el monstruo

Foto: Nosferatu

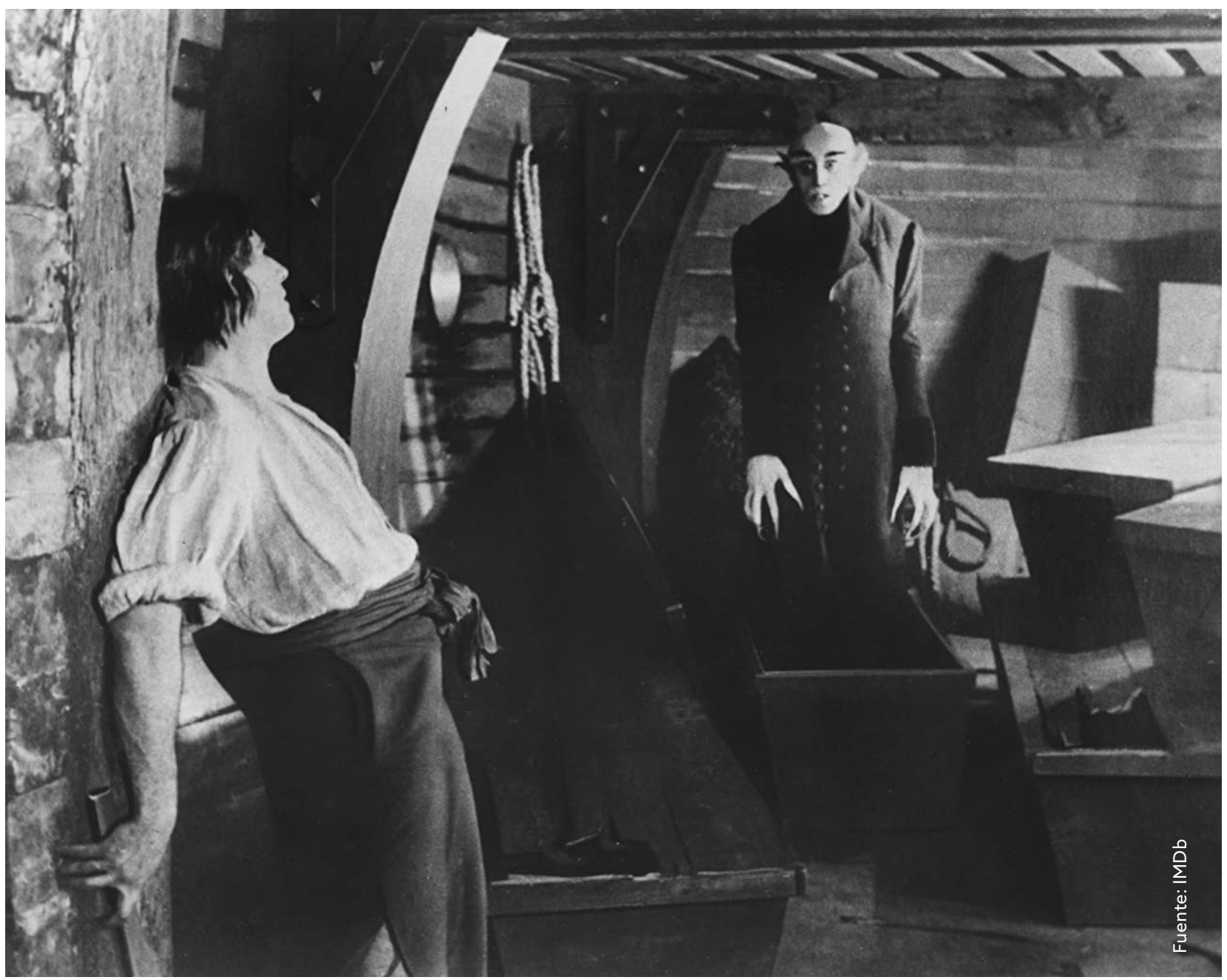


más fiel al espíritu del capitalismo. En La noche de los muertos vivientes (Night of the Living

Dead, 1968) la "epidemia" zombi se asocia con la radiación nuclear, pero en películas posteriores Romero relaciona los virus con los zombis. En Colapso: exterminio brutal (The Crazies, 1973) el derrame accidental de un arma biológica, el virus "Trixie", provoca que los habitantes de un apacible condado norteamericano se conviertan en asesinos. En El amanecer de los muertos (Dawn of the Dead,1978) el origen de los zombis es un misterio, pero las autoridades especulan que se trata de un virus.

En esos años, David Cronenberg dirigió Parásitos mortales (Shivers, 1975) y Rabia (Rabid, 1977).

En la primera cinta los habitantes de un edificio se infectan de un parásito que los transforma en maniáticos sexuales. En Rabia, como resultado de un experimento, una mujer es portadora de una enfermedad que provoca una variante de la rabia. La chica seduce hombres para penetrarlos con un aguijón y alimentarse de su sangre. Vistas de

Foto: manera retrospectiva, estas películas se anticipan

Fausto a una época de angustias sociales en torno al sida.
En el cine contemporáneo los zombis son una imagen metafórica de los virus. Ambos se presentan como entidades sin vida, pero son capaces de destruir con eficacia los organismos - sociales o biológicos-que invaden. En Resident Evil (2002), Exterminio (28 Days Later..., 2002), El amanecer de los muertos (Dawn of the Dead, 2004), Soy leyenda (I Am Legend, 2007), Guerra mundial Z (World War Z, 2013) y Estación zombie (Busanhaeng, 2016) aparecen zombis con un poder de conquista global. Estas películas componen una versión estridente de lo que Susan Sontag (1984) denominó la imaginación del desastre.

Las crisis sanitarias del mundo globalizado son una inspiración para el cine apocalíptico de epidemias y zombis. Los virus del sida, ébola, influenza o SARS le dan un marco de verosimilitud a las ficciones de catástrofes epidemiológicas. Estamos ante un escaparate del imaginario social en el cual se exhiben, con el filtro de los géneros fantásticos, las angustias, deseos y terrores de una sociedad global siempre al borde de la autodestrucción.

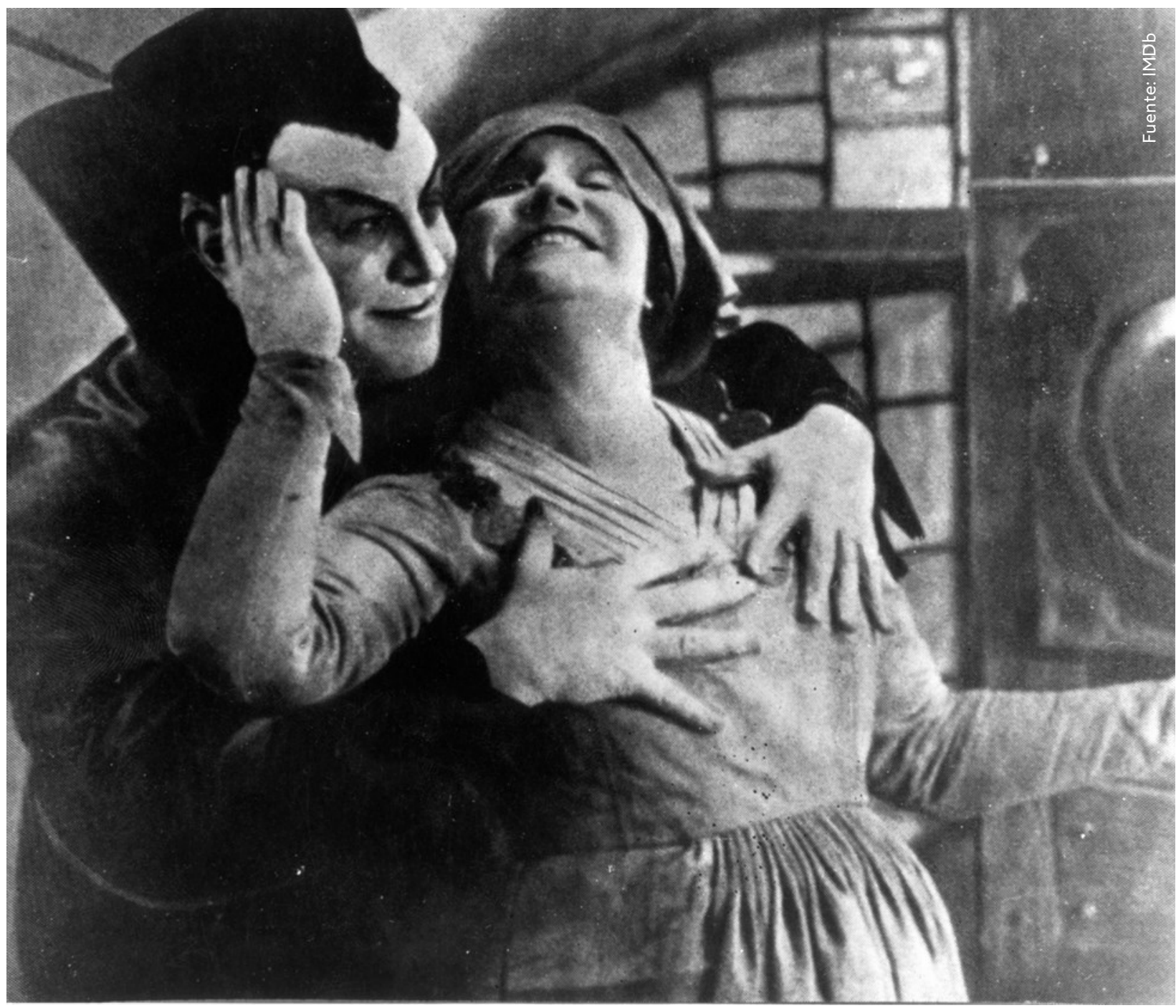




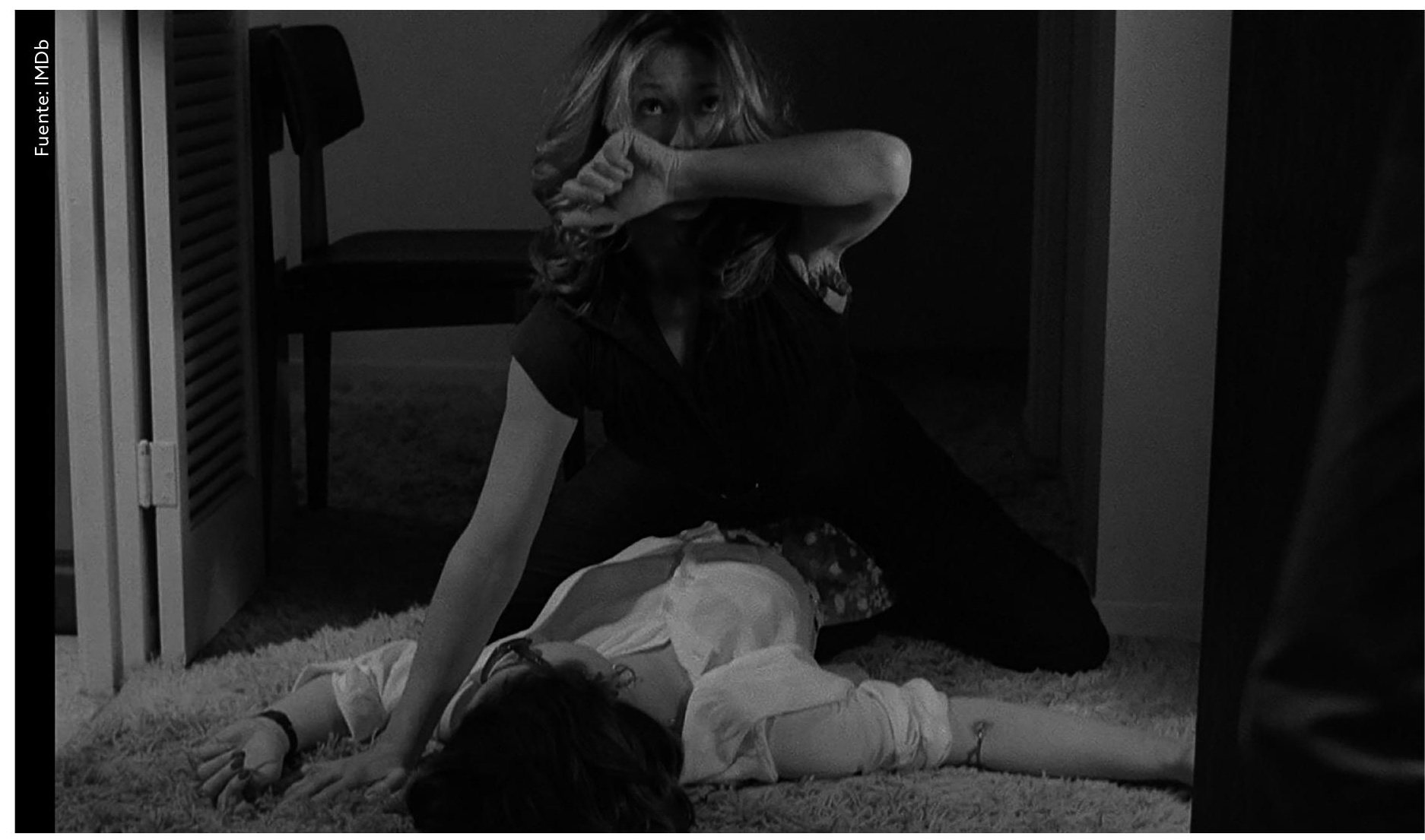

\section{Los géneros realistas}

La imaginación del desastre no solo usa géneros fantásticos para especular sobre los efectos de las epidemias. La otra máscara de la muerte tiene una apariencia realista, pero también es una expresión de la fantasía. Pocos podrían explicar mejor esta diferencia que Edgar Morin (2011): “Lo que distingue la película fantástica de la realista es que en la primera percibimos la metamorfosis y en la segunda la sufrimos sin percibirla" (p. 62).

Las epidemias de la vertiente realista forman parte, entre otros géneros, del cine negro, el melodrama, el thrillery la ciencia ficción que no integra elementos mágicos en su diégesis. Mientras el universo fantástico atiza el temor a la otredad con las transformaciones monstruosas - el enfermo deja de ser persona y pierde la empatía del espectador-, en los géneros realistas es más común que las epidemias lleguen del extranjero. De este modo, inmigrantes, turistas y refugiados se convierten en un peligro para la salud pública.

Dos películas del cine negro ilustran lo anterior: Pánico en la calle (Panic in the Streets, 1950) y Mensajera de la muerte (The Killer That Stalked New York, 1950). En ellas el rastreo epidemiológico es también una persecución policiaca. En Pánico en las calles se busca al as esino de un marinero extranjero que era portador de la peste. En Mensajera de la muerte el paciente cero
Foto: de un brote de viruela llega desde Cuba a Nueva

Rabia York con un paquete de joyas de contrabando. En oposición, los héroes son los médicos que identifican la enfermedad e intentan detener el brote con el apoyo de la policía.

La imagen heroica de los científicos que combaten las enfermedades infecciosas tiene un referente en las biografías que Paul de Kruif escribió en Los cazadores de microbios (1926). La película Arrowsmith (1931) posee el estilo épico con el que de Kruif narra la vida de los titanes de la microbiología. En algún momento de la trama, el doctor Arrowsmith renuncia a la investigación para dedicarse al trabajo clínico, pero su ánimo cambia cuando asiste a una conferencia titulada "Héroes de la salud", dictada por un investigador que, por el tema de la charla, evoca a Paul de Kruify, por su experiencia epidemiológica, se perfila como un valiente "cazador de microbios".

En Arrowsmith hay una incompatibilidad entre el destino glorioso que la ciencia le depara al protagonista y su sencilla vida como hombre de familia. La resolución del conflicto tiene un carácter trágico, pues las mayores hazañas del científico llegan al mismo tiempo que la pérdida de los integrantes de su familia. De este modo, se erige una imagen sacrificial del personaje.

Muchos héroes científicos del cine cometen una transgresión en aras del bien público. Este 


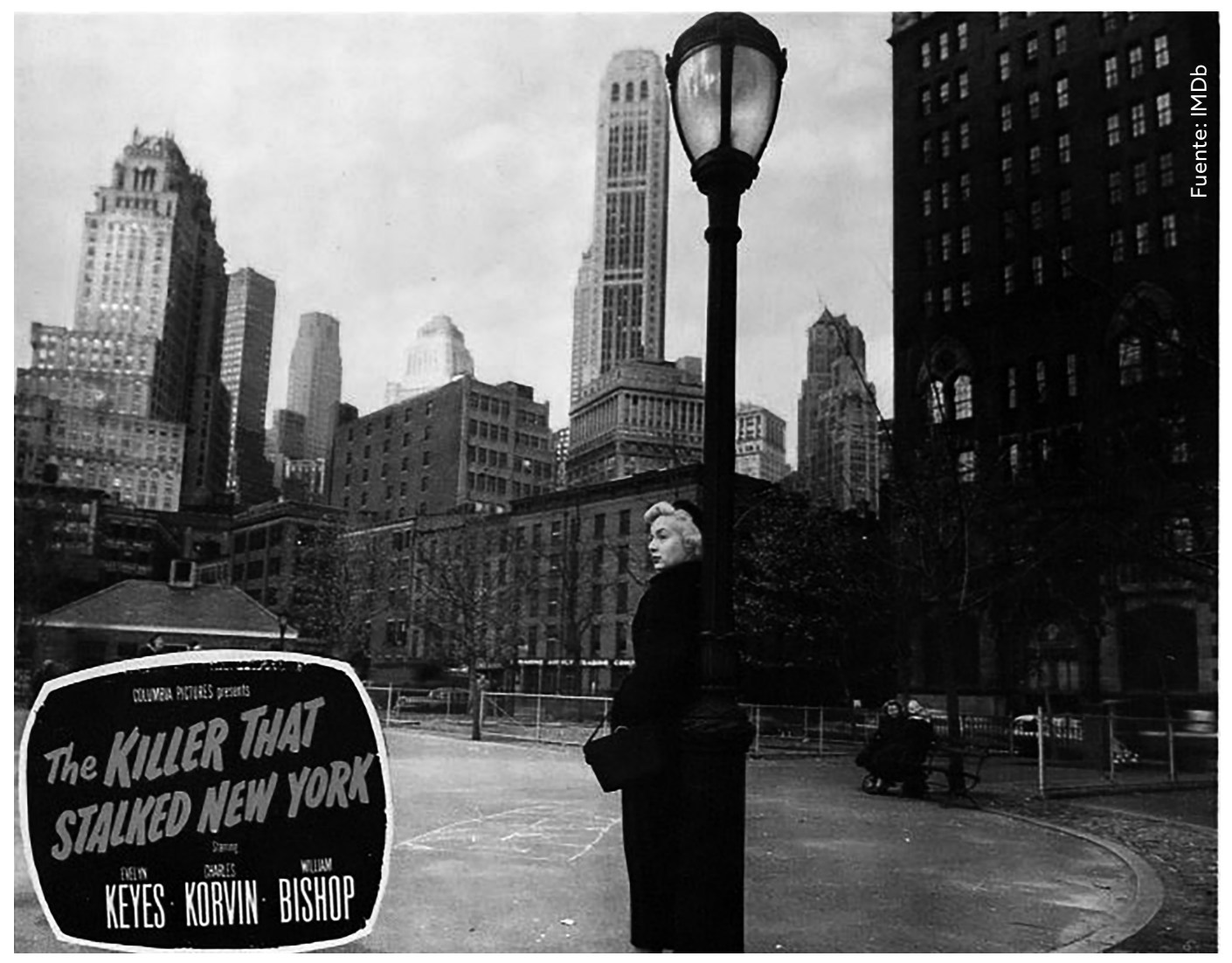

Foto:

Mensajera de la muerte modelo infractor y benefactor tiene un antecedente mítico: la historia de Prometeo, el titán que desafía a los dioses para conceder a la humanidad el dominio del fuego. En el caso de Arrowsmith, la transgresión sucede en las Antillas donde intenta probar un suero contra la peste. Los administradores de la isla rechazan la propuesta de aplicar el medicamento solo a la mitad de los pacientes para medir su eficacia. Ante la negativa, sin que las autoridades se enteren, el doctor realiza su experimento en una comunidad nativa.

La peste también es el leitmotiv de libros que han sido llevados al cine en Latinoamérica. Uno de ellos es Diario del año de la peste, novela de Daniel Defoe, 1722, que narra la magistral crónica ficticia de la epidemia de Londres de 1665. Esta narración sirvió como inspiración para El año de la peste (1979), la cual trata sobre un feroz brote de peste neumónica en el México contemporáneo.

Tres tipos de personajes ilustran el panorama catastrófico de la película: los gobernantes que se empeñan en ocultar la epidemia; las autoridades médicas que se someten, en su mayoría, a las directrices políticas de ocultamiento y la ciudadanía que, ante la falta de información confiable y de un servicio de salud eficiente, esparce rumores y acude a los remedios de charlatanes.

El año de la peste es un thriller de ciencia ficción con un componente de crítica política, pues el filme hace la advertencia de que, en caso de la llegada de una epidemia virulenta, los ciudadanos de un país como México estarían en las manos de líderes políticos inmorales y negligentes. El resultado de aquella ineptitud es más dañino que la peste.

\section{La amenaza de Andrómeda (The Andromeda} Strain, 1971) también mezcla el thrillery la ciencia ficción. Esta adaptación de la novela homónima de Michael Crichton (1969) es una de las más espeluznantes narraciones sobre epidemias. Parte de su efectividad radica en presentarse como la crónica de una crisis que amenazó a la seguridad nacional estadounidense a partir de la llegada de un microorganismo alienígena. El narrador introduce la historia como un suceso verdadero y el espectador se convierte en testigo de un reporte que ha documentado los hechos.

La amenaza de Andrómeda es otra de las ficciones que capitalizan el miedo a la guerra nuclear y bacteriológica durante la Guerra Fría. Sin embargo, el surgimiento o resurgimiento de diversas enfermedades infecciosas de tipo viral —ébola, sida, gripe aviar - se ha convertido en uno de los principales estímulos para contar historias sobre estas enfermedades o para especular sobre la llegada de variantes más agresivas.

El sida es la fuente del conflicto en decenas de melodramas que exploran el duelo, la tristeza y la voluntad de vivir de los personajes. And the Band Played On (1993), Filadelfia (Philadelphia, 1993) 
y El club de los desahuciados (Dallas Buyers Club, 2013) son ejemplos relevantes.

Elvirus motaba de la película Epidemia (Outbreak, 1995) provoca fiebres hemorrágicas. Este thriller plantea que el virus llega desde África a Estados Unidos por la importación ilegal de un mono capuchino. La trama tiene familiaridad con un evento real de alarma sanitaria por el brote de ébola en los monos de un laboratorio de Reston, Virginia, en 1989. El suceso fue popularizado con un estilo alarmista por Richard Preston en el libro Zona caliente (1994).

Las enfermedades respiratorias por infecciones virales han inspirado películas como Contagio (Contagion, 2011) y Virus (The Flu, 2013). Ambas tienen un antecedente en la pandemia de influenza del año 2009. En la primera, el brote comienza en Hong Kong y llega a Estados Unidos por medio de una mujer que visitó la región. En la segunda, una epidemia de influenza se propaga en Corea del Sur a partir de la llegada de un grupo de inmigrantes ilegales.

La mayor parte de estas películas reproducen el modelo asociado a la figura benefactora y sacrificial de Prometeo. Los científicos se preocupan por la salud pública y, en su afán de ayudar, rompen reglas de distintos tipos: procesos de investigación, medidas de seguridad personal, leyes civiles y militares. En Epidemia (Outbreak, 1995), el héroe es un científico militar que desafía a su mando para salvar a las víctimas del virus. En Contagio (Contagion, 2011), la científica Ally Hextall viola el protocolo de investigación y prueba ella misma su vacuna.

Varias películas de la vertiente realista recurren a una estrategia similar a la de Daniel Defoe en el Diario del año de la peste: contar una ficción con apariencia de verdad a partir de un suceso real. Incluso las películas que más se apegan a los hechos históricos suelen construir sus narraciones con estructuras genéricas. Por ejemplo, And the Band Played On está basada en un trabajo periodístico, pero es un melodrama; por lo tanto, es un producto de la fantasía humana como las películas de vampiros. El cine no es un espejo de la realidad; en todo caso, es una proyección del imaginario social que utiliza el disfraz de los géneros para expresar con diferentes tonalidades las fantasías de la imaginación humana.

\section{Referencias:}

Esiner, L. (2013). La pantalla diabólica. Panorama del cine clásico alemán, Buenos Aires: El cuenco de plata. Martínez, J. (2010). Vampiros y zombis posmodernos. La revolución de los hijos de la muerte, Barcelona: Gedisa. Morin, E. (2011). El cine o el hombre imaginario, Barcelona: Paidós.

Foto: $\quad$ Sontag, S. (1984). Contra la interpretación y otros ensayos Nosferatu Barcelona: Seix Barral.

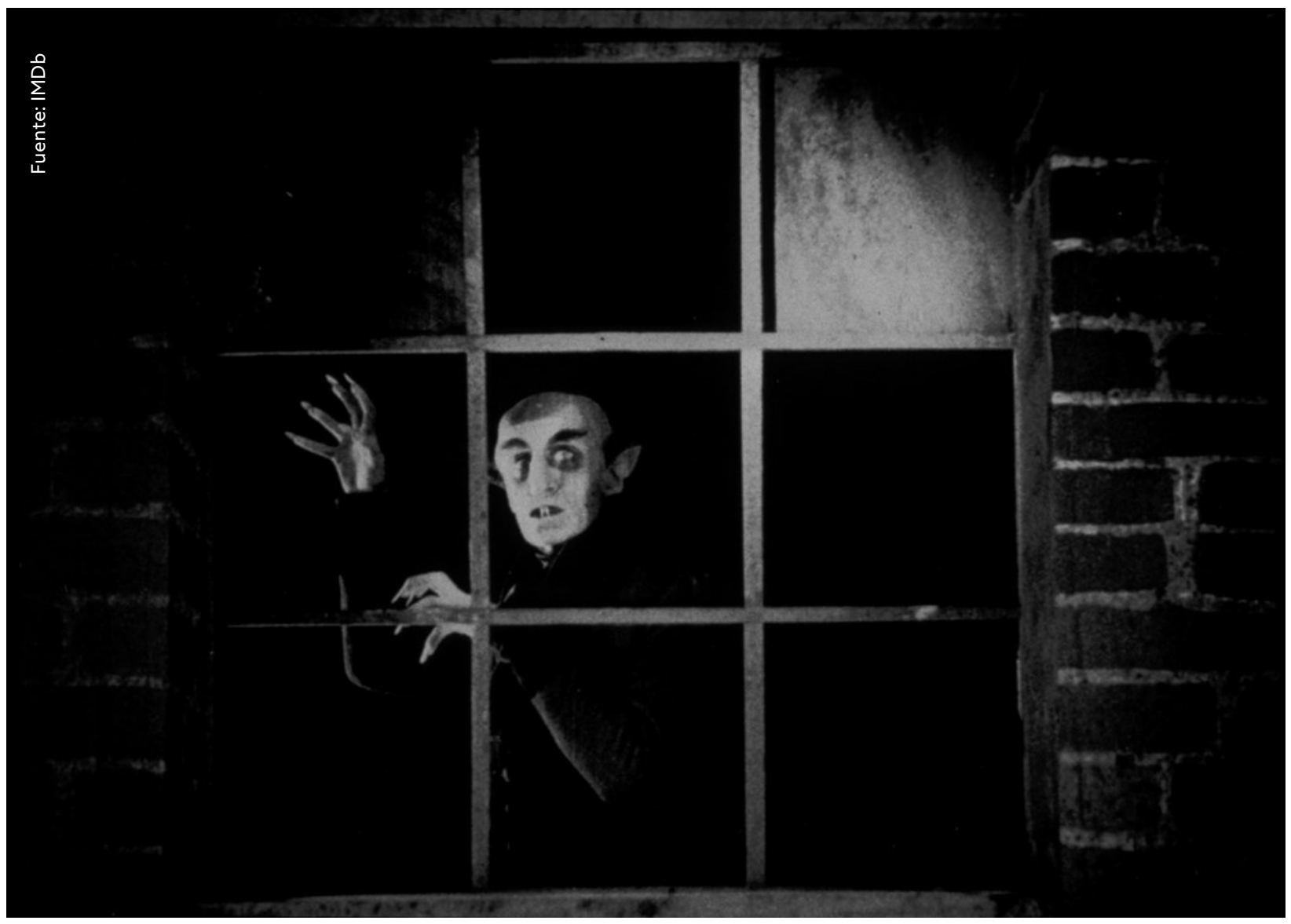

